\title{
National Language Policy and the Search for National Integration in Nigeria
}

\author{
Emmanuel O. Ojo*
}

Department of Political Science, University of Ilorin, Ilorin, Kwara State, Nigeria

\begin{abstract}
At the root of the dilemmas of national integration in Nigeria is the country's search for a lingua franca. No doubt, in a plural and deeply divided society like Nigeria, a national language is seen as unifying symbol. The thrust of this paper therefore is an in-depth analysis of the politics of using language as mechanism for national integration cum the accompanying problems. The paper also considers language mix on comparative basis. The paper however infers that rather than a fruitless search for a lingua franca, Nigeria will be better off if the dominant language in each zone of the country is developed and adopted as such.
\end{abstract}

Keywords: Lingua franca, Multi-Lingualism, Integration, Language, Assimilation.

\section{INTRODUCTION}

....in the absence of common, nationwide ethnic and cultural identity, new nations proceed to plan and create such an identity through symbol that can lead to mobilization and involvement above, beyond and at the expense of pre-existing ethnic/ cultural peculiarities ... it is at this point that a national language is frequently involved ... as unifying symbol [1].

The above quotation epitomizes the central argument of this study, the thrust of which is to explore the imperatives of national language policy or lingua franca as an integrative mechanism in a plural and deeply divided society like Nigeria [1]. This becomes necessary in the sense that language is widely recognized to be an important theme of symbolic policy-making, and a potential instrument of National integration or mobilization, in multi-ethnic societies [2]. Although Nigeria does not appear to have any definite, distinctive or comprehensive national language policy, the issue of a national language has featured prominently in the country's academic, constitutional and political debates [3]. Echoing the significance of national language(s) for Nigeria, Fafunwa (1986 see also [5]), affirms that "all national questions directly or indirectly relate to the question of language particularly in a bilingual or multi-lingua country like Nigeria $[4,5]$.

It is important to observe that a national language has been successfully adopted as a unifying factor in a number of African countries like Tanzania and Somalia, whose lingua franca are Swahili and Amharic respectively. But unlike Tanzania and Somalia, the choice of a lingua franca in Nigeria is problematic. The primary reason for this is not unconnected with the avalanche of languages and dialects which scholars have put at different figures [6,7]. Probably; the most authoritative survey is that of Hanford, which

*Address correspondence to this author at the Department of Political Science, University of Ilorin, Ilorin, Kwara State, Nigeria; Cell: 08033822383; Home: 022008330; Email: eojo12000@yahoo.com identify as 394 indigenous languages spoken within the territorial boundaries of the country [8]. But a number of scholars suggest that the actual number may well be higher considering the fact that a closer investigation of the Ijo language in Rivers State has been found to be 17 different languages, rather than a single dialect [9]. Even so, some people have come up with ludicrous figures ranging between 400 and 600 languages. What is clear, however, is that Nigeria is extremely linguistically fragmented.

The numerous languages spoken in Nigeria have been variously classified into groups too. For example, Adekunle (2000:23-29), classifies them into four groups on the basis of their speakers' population and importance [10]. Agheyisi (1982:41-52), on the other hand, classifies them into two using the same criteria [11]. The disagreement between them stems from the fact that those languages in classes ' $A$ ' and Agheyisi's with the exception of Edo, which tops the list of minor languages, regards ' $\mathrm{B}$ ' of Adekunle's classification as major languages. The second groups of languages are the minor languages. These are spoken by 100,000 speakers or more. There are about 25 languages in this category.

By implication, this problem of multi-lingualism carries with it the commentary myths that have developed around the concept of language and the nation. The first is that multi-lingualism is a barrier to national integration. To break this myth in India, according to one estimate, out of 1,652 languages or dialects that are spoken in India eighteen of them are recognized as 'languages of India' but this kind of selection has never been both easy and easily done in Nigeria [12]. The second is that national integration necessarily involves the emergence of a nation-state with one common language [13]. The myth that multi-lingualism impedes national integration is a widespread one, and it is expressed in such views as the following:

... differences between indigenous languages keep people apart, perpetuate ethnic institutes, weaken national loyalties and increase the danger of separatist sentiment [13]. 
With the above overview of the national language imperative and the accompanying dilemma vis-à-vis national integration in Nigeria, the rest of the study proceeds to comparatively and historically examine different language mixes juxtaposing it with the possibility of enhancing national integration. The second part of the study dwells extensively on Nigeria's national language policy bringing out the flaws and the challenges. The study infers that for lack of continuity and political will national language policy and Nigeria's search for national integration may be a mirage after all.

\section{LANGUAGE MIX: A COMPARATIVE AND THEORETICAL PERSPECTIVE}

Races do mingle and produce a miscegenated offspring. Language can be infused so as to enrich or replace or efface the original mother tongue. Culture can be diffused too so as to produce permeated complex when an ethnic group is subjected to an impact of another race, language or culture. For instance, until 1991, successive regimes in Ethiopia either tried to suppress the unique cultural identities of more than eighty distinct ethno-linguistic groups and, at the same time, to assimilate them into the dominant Amhara culture [14]. The tendency is to produce a crisis of existence in virtually all multi-ethnic states depending upon several sociological factors. Nnamdi Azikiwe, one-time president of Nigeria's parliamentary First Republic (1960-1966), referred to eight situations to illustrate this point [15].

First, human beings who belong to the same race and speak a common language and acquire a common culture are homogenous as an ethnic group and can be assimilated in a new society of their own make. For example, the English ethnic group belongs to the Caucasoid race; they speak English as a common language, and acquired an AngloSaxon culture in the course of the centuries. Among themselves, they are homogenous and can be easily assimilated in a new society of their making but not in others. The same holds true for the Irish, the Welsh and the Scots. In Nigeria, the Igbo, Yoruba, Edo, Efik, Ijo, Gwari, Tiv, Idoma, Jukun, Nupe, Urhobo, among others, fall into this category because individually, they had acquired a common culture from time immemorial.

Second, human beings who belong to the same race, speak a common language and acquire a different culture tend to guard jealously their homogeneity and therefore are not easily assimiliable. For example, the French belong to Caucasoid race, they speak French as a common language, and acquire Gallic as a different culture. Among themselves, they can be homogenous, but among other ethnic groups they are not easily assimilable. In Nigeria the Hausa, Fulani and Kanuri are in this second category, because individually, they belong to the Negroid race exchange for their own indigenous culture. Being homogenous in respect of their race and language, they can individually be assimilated easily among their kind; but are not easily assimilable by other cultural groups.

Third, human beings who belong to the same race speak a different language and have acquired a common culture are assimilable among their kind, but not easily assimilable among others. For example until the State of Israel was established in 1948, Jews of the world were members of the Caucasoid race; they spoke different languages, but now acquired a common culture. They were assimilated easily among their kind, but not so assimilable with other distinct groups. We cannot fit any Nigerian ethnic group into this pattern.

Fourth, human beings who belong to the same race speak a different language and have acquire a different culture are assimilable among their kind but not in others. For example, citizens of Switzerland belong to the Caucasoid race; they speak four distinct languages, and acquired a different culture.

The fifth sociological instances are human beings who do not belong to the same race, but speak a different language, and the same culture are assimilable among their kind but not in others. For example, Arabs are multi-racial, but they speak the Semitic language and have an Arabic culture. Another example is the peoples of African descent, who are citizens of the United States by birth or residence or naturalization; are multi-racial; some of them like the Shuwa Arabs speak the Semitic language and have an Arabic culture.

Furthermore, human beings who do not belong to the same race, but who speak the same language and have acquired a common culture are easily assimilable among themselves but not in others. Some Nigerian nationals are multi-racial, some of them speak different languages, and some of them have acquired a different culture by becoming either Christians or Muslims. They assimilated among themselves but not among others.

In the same vein, human beings who do not belong to the same race, but who speak the same language, and acquired a different culture are also assimilable. American citizens are multi-racial, they speak English (in some cases in addition to their mother tongue), and have different culture, depending upon their places of origin, in the case of immigrants. They assimilate among themselves but not among others. The last instance, from empirical data of language mix the world over is human beings who do not belong to the same race, but who speak a different language and have acquired a different culture are not easily assimilable. For example, AfricaAmericas are partly Negroid and Caucasoid, but they speak English and have acquired Anglo-Saxon culture. Latin America Negroes are identically situated but they speak either French or Spanish Portuguese, and have acquired Gallic or Iberian culture. Canadians are multi-racial; some of them speak English or French and have acquired AngloSaxon or Gallic culture. These three groups assimilate easily among themselves but not others $[9,15]$.

What interpretation can we give to the data yielded by these eight categories of human beings, who constitute ethnic groups, primordial, and developed to become nationalities subsequently? We should be careful not to jump into conclusions, since not all the factors responsible for human behaviour are either known or are at our disposal when studying the social consequence of ethnicity. It would appear though that where there is complete homogeneity in respect of these three factors of race, language and cultureas the case with most Nigerian and African ethnic groups the degree of assimilability of each linguistic or cultural 
group depends upon the degree of its aloofness from its primary group.

Thus, ethnicity would be intensified among this group unless agreeable external factors modify it. Thus, same line of reasoning would seem to hold good where there is a marked degree of homogeneity or heterogeneity in respect of any two of the three actor cited. But the degree of ethnicity would be less marked if the uniting factors are unimportant, in view of the United States experience, not to overlook what happened in South Africa and southern Rhodesia (Zimbabwe) before the collapse of the apartheid regime.

The conclusion we make from the data yielded and interpretations made on the eight specific situations of interracial, inter-linguistics and inter-cultural relations, is that human beings, irrespective of their racial affinity, language classification or cultural identity, tend to be more homogenous in simple societies and to be more heterogeneous in complex societies. Although in case of the latter the heterogeneity can undergo a social metamorphosis to become transformed into homogeneity. Simply stated, our thesis is to the effect that when members of a human race are congregated in an environment to build a community, they tend to be parochial at the initial stage only to become cosmopolitan later. The factors responsible for their parochialism are mainly ethnic but those responsible for their cosmopolitanness are ethnical and sociological. We deduce from this the following positions: That human beings will attach less importance to their racial, linguistic and cultural origins, so long as their individual interests are insulated from tyranny and their group attachment is insured from want, and provided that the environment in which they live is conducive to human happiness [15].

\section{EVOLVING A LINGUA FRANCA FOR NIGERIA}

The quest for national integration thus puts question on the national language problem. The assumption is that if all can communicate in lingua franca, some of the biases and chauvinisms will go away. The importance of language policy to national integration cannot therefore be overemphasized. It is against this background that Arien Amayo, identifies the absence of a well coordinated national language policy as one of the main factors militating against the various efforts to make national unity a reality. He opines that the indigenous languages (and not English as some people tend to believe), are the only possible means of integrating the numerous groups into a unified nation as well as the means of integrating or reintegrating the elite with the masses from whom they have been too long alienated [16].

However, in well over four decades of flag independence, Nigeria has witnessed little or no change in her language policy. Clause 54 of the independence constitution of 1960 states that the "business of the parliament shall be conducted in English" [17]. On 21 November 1961, during a debate on language policy, a member of parliament, Mallam A.T. Balla moved a motion in which the government was urged "to introduce the teaching of Hausa, Yoruba, Igbo and other languages into Institutions of Learning throughout the federation with a view to adopting one of them as the official language in the near future" [18]. In 1979, perhaps in recognition of the integrative potential of language of the federal government stated in section 51 of that year's federal constitution that the business of the National Assembly shall be conducted in English and in Hausa, Igbo and Yoruba when adequate arrangements have been made therefore" [19]. Section 53 of the 1989 Constitution too stated the same thing thus: (i) that English language (40 years after independence) can still be considered de facto official language of Nigeria; (ii) that despite awareness for a need for national language, the federal government is evidently not ready to face the possibility of an ethnic conflict by selecting any indigenous language because of the explosive political implications [2]. Hence, the National Anthem and Pledge have been translated into Hausa, Igbo and Yoruba. The language lessons of the National Youth Service Corps (NYSC) - the one - year mandatory service of Nigerian graduates are conducted in three languages, while the use of signals in these languages in public places, such as hospitals and railway stations is widespread [3].

To further promote Hausa, Igbo and Yoruba as national languages, the Political Bureau (1986) recommended, and the government approved, the following measures:

- the teaching of the three languages in all primary and secondary schools;

- the encouragement of all local governments in the country to set up centres for the teaching of at least one of the national languages, other than the one predominant in their respective areas;

- the expansion and encouragement of teachers of these languages;

- the encouragement or requirement of all federal career officers to be fairly fluent in at least one of the three national languages, other than the one predominant in their respective areas of origin; and

- $\quad$ the promotion of newspapers and media programmes in the three national languages [20].

In this connection, the government considers the three major languages in Nigeria to be Hausa, Igbo and Yoruba [21]. The foregoing are the main features of Nigeria's tacit national language policy.

In the face of an incoherent language policy coupled with the simplicity expectation that one of the three major languages, presumably Hausa would eventually and naturally emerge as both the national lingua franca and along with English, the co - official national language, a number of dilemma has set in. In other words, what set of criteria will be widely accepted if adopted in choosing a particular language for national use? Commenting on this dilemma in a country which A.H.M. Kirk-Green (1969) [22] says has well over 400 ethnic groups with some of them bigger than many independent states of contemporary Africa, Kebby, is of the view that "no Nigeria language can serve scientific and technological needs... because none is complete" [23]. Some scholars have equally argued that since English is a neutral language, no ethnic group in Nigeria can claim ownership of it, so, it will continue as an international language, with widespread use in international trade and communication [24]. While some other scholars [25] favour neither the major or minor Nigerian languages but want an entirely new language "because being neutral, no ethnic group would lay 
claim to it." Those with this school of thought have recommended that the proposed language should be entirely Nigerian in origin and should be created by mixing three or more existing indigenous languages.

Already, different names have been suggested for the proposed language, some people would want to call it "WAZOBIA", formed by integrating the three major languages: Hausa, Igbo, and Yoruba which incidentally are the languages of the major ethnic groups in the country. In fact, "WA", "ZO", "BIA", Yoruba, Hausa and Igbo words respectively, mean "come". But Ugbeneweka, who has started to construct a new language by combining different local languages in the country, would want to call it GUOSA". But whether WAZOBIA or GUOSA, proposal for a new language has been rejected by several scholars and commentators on the ground that it is fanciful and bizarre for three important reasons in Nigerian context.

First, it needs be emphasized that artificially constructed languages have never worked anywhere, since language must spring from the emotional needs and linguistic habitat of speakers. Second, it is equally impossible to learn all the rudiments of a new language to be integrated, and even if it were possible, how would the words in the different languages be put together in the correct sequence? Third, the new language cannot be "neutral", as it is claimed since it will be formed by mixing existing languages, and traces of consensus one quite remote [24].

Nevertheless, apart from the emotional problems associated with the choice of a national language, there are other practical problems confronting both the monolingual and multi-lingual options. The serious problem in this context is how to grapple with how to teach the chosen languages to those who do not speak them natively. Another is that the status of such language(s) has to be improved in terms of vocabulary enrichment and procurement of educational materials, for them to be adequately utilizable in more vital domains. Perhaps more serious problem here has to do with pedagogical problems the children of minority groups who have to be educated in the medium of the language(s) chosen, as opposed to their mother tongues, will encounter. It has been argued that such children have to grapple with the problem of understanding the language of instruction first before understanding academic concepts encoded in such language. In effect, academic progress of such children is retarded when compared with those who begin their education in a familiar linguistic medium. Added to this problem is another which is social-psychological in nature. It is believed that learning through another linguistic medium has depersonalizing effects. It may lead to a stage where a child no longer appreciates his ethnic group especially in situations where the speakers of a language are formidable and constitute a positive reference group to other groups who have to learn their language for socio-economic benefits. On account of this, some people have virtually lost their identity. A case in point are those Bamigbose sarcastically describes as Nigerians "in blood and colour, but English in tastes, in opinions, in morals and in intellect" [26], these are the problems communities associated with multi-lingualism in Nigeria and other multi-lingual new states are facing [5].

\section{CONCLUDING REMARKS}

The preoccupation of this article is the possibility of using language as an integrative mechanism in Nigeria's convoluting federalism. The snag however is that Nigeria's national language policy has not been able to evolve lingua franca with the implication that the colonial language English - continues to fill that gap. The problem poses by the adopted foreign language however is that of nationalism. Not only that, it has not been possible too to discern what Nigerians want in an integrated civil society. Is it to be Nigerian or English? That is the problem inseparable from adopting the language of the colonizers. Nigeria's multilingua society is equally faced with the problem of cultural interference. This is not unconnected with the fact that language is also an inseparable aspect of culture too.

As earlier mentioned Nigerian government is not unmindful of this dilemma, this is why the three major languages are taught at the National Youth Service Corps orientation camps. But one month's orientation programme is greatly deficient for any meaningful comprehension of an alien language. Also, in the absence of motivation and reward for mastery of another language during the NYSC programme corps members are far from being serious with the learning. Extending our searchlight to the secondary school level where pupils are to learn at least a language different from their mother tongue, state governments are not working in concert with the federal government by recruiting language teachers to handle the programme. Except federal government colleges which are really negligible going by the population of the country, state governments are not keen about the policy. Thus, dearth of language teachers has whittled down whatever impact the policy could have made. To compound the problem, the selection of the languages of the three major ethnic groups has resulted into a kind of majority/minority interests. The minority ethnic groups are feeling marginalized, thereby making them rather not sufficiently enamoured with the national language policy. In fact, several states outside the major ethnic groups do not see anything reasonable in recruiting language teachers that will teach their children the language of the "oppressors" and at the same time losing interest in the development of their own mother language. Undoubtedly, the teaching of the major languages makes the minorities feel alienated. That is the paradox of national language policy in Nigeria. It may however be better if the dominant language in each zone of the country is developed for teaching and learning at both the primary and secondary level along with English languages, than a kind of blanket imposition of the language of the dominant ethnic groups. The wisdom in this recommendation is not unconnected with the fact that a country the size of Nigeria can afford to recognize more than just three languages. Senegal does not have up to half the number of languages in Nigeria, yet she has recognized six different languages - Wolof, Pukar, Sereer, Joola (Jamaat), Madinka and Soninke - as her national languages since 1963. The decision to recognize Hausa, Igbo and Yoruba as potential candidates for the national language in Nigeria is said to be informed by the numerical strength of their speakers. Using the same yardstick, there will be no problem at all if Wolof is chosen as the national language in Senegal. This is because up to 80 percent of the national population speaks it 
either as a first or a second language. Yet, Wolof is not regarded as the sole national language of Senegal; instead six languages are given recognition as national languages. Nigeria may eventually toe the line of India which picked 18 as national language; one is not however sure of the extent to which these languages are effectively utilized now; but definite guidelines were given for their active utilization which may eventually douse the current tension.

\section{REFERENCES}

[1] Fishman JA. Socio-linguistic and the language problems of developing countries. In: Fishman JA, Das C, Eds. Language problems of developing countries. New York: Wiley, Sons 1986

[2] Banjo A. Language policy in Nigeria. In: David RS, Kwamena BE, Eds. The search for national integration in Africa. New York: The Free Press 1976.

[3] Suberu RT. Public policies and national unity, research report No. 19. A publication of development policy centre, Ibadan 1999.

[4] Fafunwa AB. Language and the national question in Nigeria. A paper presented at the National Seminar on 'The National Question in Nigeria: Its historical origins and contemporary dimensions' at Abuja, Nigeria 1986.

[5] Oyetade SO. Multi-lingualism and lingusitic politices in Nigeria. African Notes 2000; 16(1,2): 32-43.

[6] Tiffen BW. Language education in commonwealth Africa in language education. In: Dakin JL, Ed. London: Oxford University Press 1977.

[7] Bamigbose A. The English in Nigeria. In: Spender J, Ed. The English Language in West Africa, London: Oxford University Press 1971.

[8] Hansford KJ. An index of Nigerian languages. Accra: Summer Institute of Lingusitics 1976.

[9] Ojo EO. Mechanisms of National Integration in a Multi-Ethnic Federal State: the Nigerian Experience. Ibadan: John Archers (Publishers) Limited 2009.
[10] Adekunle MA. National language policy and meaning: the Nigerian situation. West Afr J Mod Lang Q 2000; 4(6): 23-9.

[11] Agheyesi RN. Minor languages and the National question: problems and prospects. Savanna Q 1982; 10(2): 41-52.

[12] Roy AN. Mechanism of intergovernmental relations, New Delhi Institute of Social Sciences, 2002.

[13] Bamigbose A. Language and national integration: Nigeria as a Case Study, Paper presented at the Second World Black and African Festival of Arts and Culture, Lagos, Nigeria 1977.

[14] Keller EJ. Ethnic Federalism, Fiscal Reform, Development and Democracy in Ethiopia. Afr J Pol Sci Q 2002; 7(1): 21.

[15] Azikiwe N. Tribalism: a pragmatic instrument for National Unity, being the text of a lecture delivered at Princess Alexandra Auditorium, University of Nigeria, Nsukka, on $15^{\text {th }}$ May, 1964 under the auspices of the Nigerian Political Science Association.

[16] Amayo A. The search for National Integration and National Identity in Nigeria since independence: the linguistic aspect, in Proceedings of the National Conference on Nigeria, Zaria 1985.

[17] Federal Government of Nigeria. The Independence Constitution of Nigeria, Government Printers, Lagos 1960.

[18] Federal Government of Nigeria. Federation of Nigeria, Parliamentary Debates, First Session (1961-1962)m House of Representatives, Lagos, Federal Government Printers, Column 3145.

[19] Federal Government of Nigeria. The constitution of Federal Republic of Nigeria. Daily times publication. Lagos 1979.

[20] Federal Government of Nigeria. The report of the political bureau. Government printers, Abuja 1987.

[21] Federal Government of Nigeria. National policy on education, Federal Government press. Lagos 1981.

[22] Kirk-Green AHM. The peoples of Nigeria. J Afr Aff Q 1969; 1(262): 4.

[23] Kebby M. Nigeria has a Lingua-Franca. Sunday times. Lagos. Q 1980; (November 9).

[24] Attah MO. The national language problem in Nigeria. Can J Afr Stud Q 1987; 21(3): 393-400.

[25] Ugbeneweka MA. Guosa language in a Lingua-Franca for Nigeria. Paper presented at LAW Conference. Benin. Q 1993.

[26] Bamigbose A. Models of Communication in Multi-Lingual States. West Afri J Mod Languages Q 1977; 4(6): 18.

(C) Emmanuel O. Ojo; Licensee Bentham Open.

This is an open access article licensed under the terms of the Creative Commons Attribution Non-Commercial License (http: //creativecommons.org/licenses/by$\mathrm{nc} / 3.0 /$ ), which permits unrestricted, non-commercial use, distribution and reproduction in any medium, provided the work is properly cited. 